\title{
Prebisch: the continuing validity of his basic ideas
}

Octavio Rodríguez*

\section{Introduction}

Prebisch's analytical contributions, which are particularly valuable and numerous in the fields of development theory and policy, have sometimes been called "pre-economics". This term is used to denote those points of view which seem to be based on and justified by common sense -for example, the desirability of industrialization and of the application of protection in order to achieve this- but which are at variance with conclusions backed up by economic science.

The present article takes an opposite view to this. It begins by briefly presenting Prebisch's seminal ideas -that is to say, the so-called "centre-periphery concept"-, going on to show succinctly that those ideas are reshaped and formalized in both economic theory and policy analyses based on the patterns of coherence of conventional economics (section 2). His basic ideas and their subsequent formal expression thus form a special field of economic theory which may be termed a "theory of underdevelopment".

This latter theory forms the main basis of Latin American structuralism. In reality, however, the true importance of that theory -that is to say, of the set of contributions by Prebisch which make it up- becomes

* Former full professor of the Faculty of Economic Sciences of the University of the Oriental Republic of Uruguay (or33@adinet.com.uy). "manifest" in its appropriateness for analysing some of the priority issues of recent Latin American development (section 3). In the light of certain notable aspects of the current technological revolution and the globalization process that accompanies it, these contributions are useful for addressing problems which seem to be getting worse, such as unemployment and underemployment, and others which repeatedly arise in the external sector. Furthermore, these conceptual bases are also useful as a framework for the debate on the conditions of viability and efficiency needed to renew the development effort.

The application of Prebisch's ideas and contributions to the present situation highlights their key (and also general) substrate: the perception of development as a dynamic of the structures of production of goods and services and of labour force employment: that is to say, as a set of changes in the sectoral and subsectoral composition of those structures which are inherent to their expansion and growing complexity.

If we go along with Prebisch's view that the market is not capable of inducing these changes alone, this means that the structural perception of development referred to earlier is hence "non-reductionist": that is to say, it is a perception whereby the analysis of economic phenomena must fit within a broader framework of social and political phenomena. This methodological implication means that we must reconsider the whole matter of the State and question 
certain quasi-minimalist positions on its role, which seem to be compromising the development of various Latin American countries and adversely affecting the already serious levels of inequality prevailing in the region.

\section{Main contributions}

The concept of the centre-periphery system was originally expressed in the essay entitled "The economic development of Latin America and its principal problems", which was republished a little later in the first five chapters of the Economic Survey of Latin America, 1949. ${ }^{1}$

It will be seen below that this concept consists of a set of ideas of a general nature expressed at a preanalytical level and thus not representing a fully formalized theory. They are clearly harmonious and complementary to each other, however, and form a new view of underdevelopment or, rather, of the characteristics and long-term evolution of the so-called underdeveloped economies in the period immediately after the war.

Prebisch refused to consider as an anomaly what he saw, in his experience, as a way of being. ${ }^{2} \mathrm{He}$ understood that underdevelopment cannot be identified with a mere state of backwardness, often attributed to the burden of non-economic factors supposedly connected with the social structure. Rather, he saw it as a pattern of operation and evolution specific to certain economies and thus deserving of a likewise specific effort to develop a corresponding theory.

This effort hinges fundamentally upon the identification of a basic content -that is to say, of a general view of the object of investigation- and takes this as its starting point. ${ }^{3}$ This view -or the basic concept mentioned earlier, which amounts to the same thingmay be briefly described through three key concepts:

\footnotetext{
${ }^{1}$ The first of these publications dates from late 1949 and the second from early 1950 . Hereafter, however, the quotations from them will refer to the publications listed in the bibliography as Prebisch (1962) and Prebisch (1973a).

${ }^{2}$ This experience is directly and specially related to the important functions he was called upon to discharge in the management of the Argentine economy during the 1930s crisis and the Second World War: especially putting into operation the Central Bank of that country and acting for a long period as its Director. For a short description of this see Rodríguez, 2001, pp. 100-104.

${ }^{3}$ The term "view" is used here in the sense given to it by Schumpeter (1971, p. 78) in his History of Economic Analysis. This term expresses and sums up the point of view that every new theory, or every renovation in depth of an existing theory, begins when a set
}

heterogeneity, specialization and unequal development. ${ }^{4}$

\section{a) Structural heterogeneity}

Structural heterogeneity refers to a prime characteristic of peripheral economies: the simultaneous existence in them, on the one hand, of activities and/or branches of production in which the average productivity of labour is normal, in that it is relatively close to that permitted by the available techniques, together with others in which productivity is quite high, in that it is relatively similar to that prevailing in the main industrial centres, but also, on the other hand, substantial numbers of technologically backward activities in which the levels of productivity are very limited: well below those of the other, "modern" activities.

Of these two broad classes of activities, the former generate true employment, while the latter are responsible for underemployment. This simultaneous existence of true employment and underemployment -of one labour force where productivity is high, side by side with another where it is low-is a directly visible expression of structural heterogeneity. ${ }^{5}$

The basic concept also accepts the fact that underemployment tends to persist over time. In essence, underemployment reflects a huge supply of redundant labour whose dimensions seriously compromise the possibility of rapid absorption of the labour force as a whole into activities with normal or high levels of productivity. Continuing to view this from the supply

of key hypotheses is assembled which express the fundamental content of the new ideas. It is from such a basic content that different formal expressions are developed -different formal theories structured with academic rigour- in whose construction the original content is reshaped and refined.

${ }^{4}$ Using these concepts, sections $2 \mathrm{a}, 2 \mathrm{~b}$ and $2 \mathrm{c}$ below refer briefly to the content of Prebisch's basic concept. Section 2d, for its part, refers to various works by Prebisch himself in which this content was progressively formalized. These works are mentioned in order to "manifest" the decisive importance of his contribution to Latin American structuralism. There is no intention, of course, of belittling the great contribution made to this approach by ECLAC and various authors associated with it.

${ }^{5}$ The underemployed, employed and openly unemployed make up the economically active population (EAP). It should be noted that the first of these three categories is defined solely and strictly on the basis of the physical productivity of labour, so that although it may come close, the notion of underemployment does not coincide with "informality" or "marginality". This differentiation does not mean denying that they all seek to take account of phenomena related with social exclusion in peripheral economies such as those of Latin America. 
side, this redundancy is also seen to be associated with demographic variables, that is to say, the increase observed in the growth rates of the population as a whole and the active population of peripheral countries when their mortality rates go down, while their birth rates take longer to decline. From the point of view of demand, it may be noted that the labour-saving nature of the technical progress originating in the main centres and the relatively small rates of accumulation and growth that can be reached on the periphery also make it more difficult for underemployment to be converted into employment there. ${ }^{6}$

Underemployment persists in the stage in which the development of the periphery comes to be led by expansion of the industrial sector. Although it persists, however, there are significant changes in its composition in this stage. The attraction exerted by the cities, or the straightforward expulsion of labour from backward agricultural activities, mean that in urban areas the percentage of the labour force which is underemployed (employed in low-productivity occupations) is higher than nationwide underemployment, while in rural areas it is correspondingly lower. In other words, over time structural underemployment shifts from rural to urban areas, while nevertheless remaining a key expression of heterogeneity. ${ }^{7}$

\footnotetext{
${ }^{6}$ The persistence of structural underemployment is referred to in Prebisch, 1973a, pp. 69-70.

${ }^{7}$ For an early overall reference to the problems of the periphery connected with the agricultural sector, see Prebisch, 1973b, pp. 47-51 (the first version appeared in 1951). This document contains the following telling assertions: "This is a very important aspect of the problem of the spread of technical progress in Latin America, but has not yet been given all the attention it deserves. It is possible that, because of the shortage of capital to absorb the surplus labour force caused by agricultural mechanization, the saving of labour may have led ..... to poor employment in rural areas or big concentrations of city-dwellers .....". "Not much can be done to raise the standard of living of the masses tilling the soil (especially the poor soil of traditional agriculture) unless the redundant rural population due to technical progress is eliminated and that part of it which is not needed for working the new land opened up for cultivation is reabsorbed into activities with satisfactory levels of productivity". It may be inferred from such assertions that the process of structural change that makes up development is linked with the transformation of the peripheral economies from rural to urban and from agricultural to industrial. The employment problems of those economies are likewise seen to be linked with such changes. By way of example, it may be noted that in Brazil in 1960, underemployment affected nearly 50\% of the working population and about three-quarters of it still corresponded to agricultural underemployment.
}

\section{b) Production specialization}

The specialization of the production structure of the periphery was originally connected with the long period in which its growth depended on the export of foodstuffs and raw materials. Later, when industry spontaneously became the main source of growth, the initial primary export specialization conditioned the new pattern of development. This specialization at the starting point (in extreme cases, the almost exclusive production of primary exports and almost complete absence of exports of manufactures) means that industrialization progresses from simple to more complex levels. In other words, a country begins by producing simple consumer goods and only gradually progresses to the production of more technologically complex goods: consumer durables, intermediate goods, and certain capital goods.

Precisely because countries begin with simple goods and then gradually embark on the production of other goods located "further back" in the production chain, the pattern of industrial development peculiar to the peripheral countries means that the specialized nature of their production structure is maintained, because in view of the initial specialization of the export sector in primary commodities and the need to progress from simple to more complex levels typical of that pattern, the degrees of intersectoral complementation and vertical integration of production achieved by the periphery are only small or incipient.

The foregoing basic argument is clarified and complemented if we take into account Prebisch's assumptions on technical progress, which he perceived as a variable exogenous to the economy. He also accepted that such progress is more rapid in industry than in primary production, and also more rapid in industrial activities situated "further back" in the production chain, especially in the production of capital goods, in which it is embodied. This acceptance means that the industrialization of the periphery repeatedly has to progress from simple to more complex levels, since it is obliged to embark on activities in branches where technical progress is slower. This means, in turn, that the specialization of the periphery persists, while its possibilities of achieving greater intersectoral complementation and vertical integration of production are repeatedly limited. ${ }^{8}$

In addition to the low level of initial development of industry, the new specialization aspect just mentioned

${ }^{8}$ With regard to these views on technical progress, see Prebisch, 1962, pp. 1 and 4. 
has some other noteworthy connotations. On the one hand, there is repeated difficulty in exporting manufactures and thus achieving successive increases in the value of total exports. ${ }^{9}$ On the other, there tends to be ever-increasing growth of imports, because of the low level of complementarity of domestic production and/or the demand for imports of goods located "further back" in the production chain, because of the low level of vertical integration. These implications of specialization, regarding the behaviour of exports and imports, lie of course at the root of the persistent tendency of the peripheral countries to register trade deficits, which are repeatedly observed during the process of spontaneous industrialization. This tendency is also responsible for the fact that external saving -i.e., the inflow of foreign capital- can only make a limited and supplementary contribution to the development of the periphery. ${ }^{10}$

\section{c) Unequal development}

The unequal (bipolar) nature of development in the centre-periphery system is related primary with the special structural features described in previous sections. These features mean that the production structures of the peripheral economies keep on changing over time, especially during the stage in which the expansion of industry spontaneously acts as their leading source of growth. ${ }^{11}$ As pointed out in the

\footnotetext{
${ }^{9}$ The difficulty in achieving such increases is also connected with the decline in primary commodity prices that would result from a major increase in their volume, because of the low income-elasticity of the demand for them in the main centres.

${ }^{10}$ A growth pattern (the most simple in analytical terms) in which no effort is made to export manufactures would mean that industrialization would have to progress with a gradual decline in the export coefficient and the degree of openness to the exterior. It can be demonstrated that reduction of the share of foreign ownership in the total assets of the periphery (defined as the percentage ratio between the total value of that property and the value of the external debt regarding that total) is a logical requisite for continued growth, in the growth pattern in question. Such a requisite must also be satisfied in analytically more complex cases where both coefficients increase, where it is a case of peripheral economies structurally conditioned by external constraints. In the final analysis, the argument is based on the accentuation of that restriction because of the effects produced in the long term on the balance of payments current account by the remuneration of foreign capital. With regard to this argument, which is taking on renewed importance nowadays, see ECLAC, 1953, pp. 52-54.

${ }^{11}$ The documents by Prebisch and ECLAC maintain that problems of employment and those caused by the tendency towards external imbalances are connected with the patterns of change in the structures of production and employment due to the "spontaneous
}

previous observations, however, even after they have been changed these structures continue to be heterogeneous and specialized. Those characteristics and their persistence are in marked contrast with those of the great industrial centres: the latter also go through ongoing changes and become more complex, but they maintain or even further increase their already comparatively high degrees of homogeneity and diversification.

Development in the centre-periphery system is also unequal in a second respect: average income (per employed person and/or per capita) tends to differ considerably between its two poles. The reason for this difference is the disparity between the growth rates of the productivity of labour, which is higher in the centres because technical progress is faster in them. Another factor which operates in the same direction in peripheral economies is the persistence of heterogeneity in them: that is to say, the existence of great masses of workers employed in very low-productivity activities, which adversely affect average productivity. A further factor which causes average incomes to be lower is the deterioration in the terms of trade, ${ }^{12}$ for the decline in the relative prices of the peripheral countries' exports means that in the sectors producing those goods the workers' income increases less than the productivity of labour. The opposite is the case, however, in the export sectors of the central economies.

It is easy to see that the differences in incomes and the inequalities of the production structures are related with each other. The differences in incomes, like the unequal performance of labour productivity levels and the deterioration in the underlying terms of trade, mean that the peripheral economies are weak in terms of their capacity to achieve and maintain high rates of accumulation. It will likewise be readily understood that this weakness makes it harder for those economies to overcome their structural backwardness or, more precisely, adversely affects their possibilities of gradually reducing their prevailing heterogeneity and specialization. In turn, the persistence of such structural conditions means that there will also be a tendency for the inequality of average incomes to persist between the two poles of the system.

industrialization" which gained pace in various Latin American economies as a result of the Great Depression and the Second World War. In contrast is the "planned industrialization" approach which forms the essential basis for a development policy capable of ensuring that the changes in those structures follow a proper path. ${ }^{12}$ This question is referred to briefly again in the following section. 


\section{d) Formalizing the initial content}

In order to gain a fuller perception of the significance and importance of Prebisch's basic concept, we should also associate it with another of his contributions and briefly consider its different formal expressions.

The first documents in which this concept was put forward contain the first two formal expressions of the theory of deterioration of the terms of trade. An "accounts version" (using only ratios of definition) describes it accurately and brings out its hidden significance: that is to say, its influence on the differentiation of average incomes between the centre and the periphery. ${ }^{13} \mathrm{~A}$ second formal expression, known as the "cycles version", was designed to explain the phenomenon of such deterioration on the basis of cyclic movements in the central economies and the way those cycles spread from those economies to the periphery. ${ }^{14}$ In the first half of the 1950 s, various equally precise formal expressions were developed of another two theories, one designed to explain the tendency towards an over-abundance of labour, and the other the tendency towards an external imbalance. ${ }^{15}$ In 1959 a third formal

\footnotetext{
13 The significance of the deterioration in the terms of trade and its perception as a long-term trend typical of centre-periphery relations was already recognized in the study Postwar Price Relation between Underdeveloped and Industrialized Countries, prepared in February 1949 under the direction of Professor Hans Singer.

${ }^{14}$ Everything seems to indicate that the terms centre and periphery were used for the first time in 1946. The following assertions by Prebisch illustrate the meaning then given to them: "Why do I call the United States the cyclic centre? Because that country, because of its size and economic characteristics, is the starting point of the impulses resulting in the expansion and contraction of world economic activity, and especially that of the Latin American periphery. I believe that the cyclic movement is universal, that there is only a single movement which spreads from country to country ...... but with markedly different characteristics, depending on whether it is a question of the cyclic centre or the periphery" (Prebisch, 1946, pp. 25-26). Later on, the centre and the periphery came to be conceived in the light of the nature of their production structures and to be related not so much with cyclic movements as with the long-term development of those structures, within the system that they formed. The "cycles version" of the theory of deterioration corresponds to one of these concepts, while the "industrialization version" mentioned below corresponds to the other.

15 Both of these were already outlined in the initial documents mentioned earlier but were expressed more precisely in other documents during this half of the decade. Of these, special mention may be made of two documents: Problemas teóricos y prácticos del crecimiento económico (Prebisch, 1973b; first version: 1951), and La cooperación internacional en la política de desarrollo latinoamericano (Prebisch, 1973c; first version: 1954).
}

version of the theory of deterioration of the terms of trade was published, seeking to explain this as the natural result of the industrialization process or, more exactly, the forms and characteristics of spontaneous industrialization in peripheral economies. ${ }^{16}$

Thus, in the course of the 1950s suitable formal expressions were being made of those key aspects of the initial content needed in order to make the interpretation of the long-term development of those economies intelligible and coherent. In other words, what may be termed a "theory of underdevelopment" was worked out, made up of the combination of the basic content and of the various theories which replicate, in abstract form, the phenomena of external imbalance, deterioration of the terms of trade, and structural underemployment.

The mere fact that this set of theories comply with the logical requirements usually demanded in conventional economics entitles them to be considered as forming a "theory of underdevelopment". It should also be borne in mind, however, that they were prepared in close connection with economic policy analyses which were also carried out with precision, so that they too complied with the same requisites of logic and internal coherence.

Only brief reference needs to be made to the economic policy proposals. The first field which may be mentioned is that of resource allocation, for which criteria aimed at optimizing the accumulation effort are established, both with regard to the form of distribution between production for the domestic market and production for export and with regard to the impact of that effort on agriculture and the possible effects of agricultural modernization on employment problems. The second field concerns "international cooperation" and covers such key issues as protection, Latin American integration and external finance. Policy bases are established for all of these which are compatible both with each other and with the resource allocation criteria, with the aim of achieving a pattern of reinsertion in the international economy which is compatible with sustainable growth and is also efficient. ${ }^{17}$ The third field revolves around the idée-force

\footnotetext{
16 The "industrialization version" forms part of the article by Prebisch (1959) entitled Commercial policy in the under-developed countries. The basic arguments of this theory are set out in Rodríguez, 1980, pp. 108-122.

17 The resource allocation criteria and international cooperation policies are referred to respectively in the two documents mentioned in footnote 15 above. Both these documents maintain that "planned industrialization" is the essential path for the development of the
} 
of planning, as reflected in the development of instruments designed to help the State to design and implement long-term development policies capable of attaining the objectives of continuity and efficiency. ${ }^{18}$

The above-mentioned theory of underdevelopment, or, if preferred, the existence of a systematic appraisal of the characteristics and tendencies of "peripheral status" in economic matters, serves as an explicit or implicit point of reference for many of the Latin American approaches to development. This is why they display common features which differentiate them from the theories in this respect that come within the framework of conventional economics. ${ }^{19}$ This special quality clearly imbues the works in which Prebisch tries to make an interpretation of Latin American development which transcends a purely economic approach: that is to say, a long-term interpretation which is both economic and socio-political. ${ }^{20}$

peripheral economies, and seek to outline ways of following that path without setbacks. It should be borne in mind that neither these nor other documents advocate industrialization at all costs or excessive and unlimited closure of the peripheral economies to the exterior: positions which have often been insistently attributed to ECLAC. On the contrary, these documents emphasize the need to expand different types of activities only for reasons of relative economic gain and to keep them exposed to the stimulus of external competition through moderate and decreasing levels of protection. Temporary financial support, together with what Prebisch called "asymmetrical protection" -i.e., more rapid reduction of protection in the centres than on the periphery-, are elements of international cooperation which will lead to a scheme of international division of labour that will gradually extend to the industrial sector. This new scheme of production and trade, which is seen to be beneficial for both poles of the system, may be termed "joint industrialization". ${ }^{18}$ In this field, an early work by ECLAC (1953) bore the title Estudio preliminar sobre la técnica de programación del desarrollo económico. Planning naturally means that the State must actively participate in the process of industrialization and development, leading it forward in a deliberate and determined manner. This position must not be identified with over-intervention, however, as the documents of that institution fully recognize the importance of the market and advocate different degrees and types of intervention, according to each particular case.

19 The book Cincuenta años de pensamiento de la CEPAL: textos seleccionados (ECLAC, 1998) covers a broad range of such approaches, and the foreword by Ricardo Bielschowsky contains a useful summary of them.

${ }^{20}$ These efforts were mainly reflected in three of his books: Hacia una dinámica del desarrollo latinoamericano (Prebisch, 1963), Transformación y desarrollo: la gran tarea de América Latina (Prebisch, 1970), and Capitalismo periférico. Crisis y transformación (Prebisch, 1981). They also contain various other undoubtedly important contributions by Prebisch to Latin American structuralism which will not be dealt with in this essay, which is limited to the subjects enumerated in the Introduction.

\section{The continuing validity of structuralism}

Everything indicates that the technological revolution which is under way and the accompanying process of globalization are responsible for the efforts to reformulate the theory of technical progress which have been made in the last fifteen or twenty years. The new approaches depart from neoclassical usage (and that of Prebisch himself), which sees such progress as exogenous and embodied in capital goods. These new approaches now consider technical progress as accumulative and as endogenous to enterprises and economic systems. ${ }^{21}$

It is considered that the revolution in question -or, if preferred, the installation and rapid spread of a new techno-economic model ${ }^{22}$ is also accompanied by a difference between the capability of the great centres to generate and incorporate technology and the corresponding capability of the peripheral countries. At the beginning of a period in which technical progress is taking on renewed dynamism, the peripheral pole lags behind or is at a disadvantage. It is held that this lag at the starting point means that this pole will have less capability to make successive technological advances in the future. In other words, it is accepted that the initial disadvantage-since it involves a smaller accumulation of scientific and technical knowledge and research and development experience- tends to bring about its own reproduction: i.e., it tends to persist over time. There is yet another factor, however: the size of the enterprises and economies of the centres -so much greater than those of the periphery- represents another decisive element that further increases the latter's disadvantage in coping with the speed of technological change, together with their smaller capacity to cover the costs and risks that such change involves.

These are the basic reasons why it is recognized in the specialized literature ${ }^{23}$ that the new model brings with it differentiation of the rates of technical progress

\footnotetext{
${ }^{21}$ For different versions of the new "endogenism", see Burgueño and Pittaluga, 1994. The same subject is dealt with at length in Malerba and Orsenigo, 2000.

${ }^{22}$ With regard to the concept of techno-economic model, see Freeman and Pérez, 1988.

${ }^{23}$ Various authors (such as Verspagen, 1993) refer to the role of technological disparity in competitiveness and, hence, its influence on the performance of countries which are lagging behind. A number of recent analyses on the impact of the technological revolution on the development of such countries are summarized and compared with ECLAC approaches from different periods in Hounie and others, 1999.
} 
between the centre and the periphery or, to put it in a nutshell, "technological disparity" between them.

As we shall see in the following sections, this disparity has important connotations for the analysis of employment and external sector problems, and such analysis, for its part, backs up the views on the need for certain basic requisites for the viability and efficiency of the development of the periphery.

\section{a) Employment problems}

Consideration of the employment problems of a typical economy over a very long period of time backs up certain hypotheses on the subsequent evolution of such problems when this is left to the play of the market forces. ${ }^{24}$

The first hypothesis concerns open unemployment. It is generally recognized that it is tending to increase in both the centres and the periphery and that this trend is connected with the saving of labour due to rapid technological progress. It is also recognized in many cases, however, that this tendency is more marked in the periphery, and especially in the Latin American economies. It is noted in this respect that in these economies the new model began to be applied within a context of extremely rapid external openness, in economies which already registered unfavourable levels of productivity and competitiveness, thus endangering the survival of various industrial and other production activities.

This phenomenon, however, which was noticeable in the 1990s, is considered to be less important than the long-term effects of the new model and the accompanying technological disparity. In view of this disparity and the external openness which continues to be maintained, it may be expected that while many activities producing goods and services will be viable in the peripheral economies, many others will be out of their reach. Thus, the slow and difficult process of trying to catch up on technologies which are constantly being renewed will tend to be reflected in problems of high and persistent open unemployment, even if

\footnotetext{
24 The case studied is that of Brazil, for which structural underemployment was estimated at various points during the period from 1960 to 1996 . It may be noted that in this case underemployment displays similar trends in all six of the different forms of calculation used for its estimation. One of these estimates is summarized and commented upon in Rodríguez, 1998. For reasons of brevity, no detailed reference will be made here to the quantitative information on which the hypotheses described in the following paragraphs are based.
}

relatively high rates of GDP growth are recovered and/ or maintained.

The second hypothesis concerns the already existing underemployment or, more exactly, the difficulties now being faced in trying to absorb this labour. In the past, under the model known as "Fordism", rapid growth was accompanied by negligible levels of open unemployment, and there were clear tendencies towards a fall in structural unemployment, that is to say, the absorption of the labour force in question in high-productivity activities. ${ }^{25}$ Under the new model, however, this possibility is limited, if not completely prevented, by the presence and persistence of openly unemployed workers who compete with the existing body of underemployed workers for jobs which are relatively scarce because of the technological disparity.

The third hypothesis concerns the possible incidence of the new model on the expansion of urban underemployment. The information on the previous model reveals that, under it, slow growth gave way to an outright increase in that form of underemployment, in both relative and absolute terms. This increase may be considered to be the result of successful survival strategies in which the material wherewithal for survival is obtained through jobs which are of low productivity but are nevertheless capable of averting the still greater problem of open unemployment and thus preventing its excessive expansion.

Recent experience, however, reveals that the high levels of open unemployment have been accompanied by a reduction in urban underemployment in both relative and absolute terms. Although the available information is scanty, it thus gives grounds for thinking that the introduction of the new model does not only cause difficulties in terms of open unemployment but also gives rise to obstacles to the expansion of underemployment, thus preventing the success of the underlying survival strategies. ${ }^{26}$

\footnotetext{
${ }^{25}$ It should be noted that the absorption of underemployed labour does not merely mean the hiring of labour in high-productivity activities, on a wage-earning basis. Its definition is broader: absorption is considered to mean raising the productivity of labour from the low levels typical of underemployment to higher levels corresponding to true employment. In this sense, employment is considered to comprise various forms of labour relations and/or "occupational status" (employer, own-account worker, unpaid family worker) and not just those involving wage labour.

${ }^{26}$ A good illustration of this is the very widespread reorganization of the sale of consumer staples. This is now carried out by big oligopolistic firms which not only compete advantageously with small shopkeepers but may well also be affecting the
} 
All in all, the foregoing considerations reflect a sort of impasse. On the one hand, the rate of growth alone no longer holds out hope of a gradual albeit slow solution of employment problems, through the creation of jobs of high or moderate productivity. On the other hand, nor do there seem to be any possibilities of relieving these problems through the lesser evil of underemployment. Thus, in the new model, the problems referred to earlier would appear to be at the root of lasting situations of social exclusion whose persistence may lead to the emergence and repetition of extremely critical conflicts.

\section{b) The external bottleneck}

"Technological disparity" is associated with a trend towards trade deficits which seems to be taking a similar form -similar in more than one sense- to that which existed in the stage of industrial expansion carried out in the context of the old "Fordist" model. The arguments regarding this trend are also similar to those used by Prebisch and ECLAC, as briefly described earlier, and may be viewed as a renewed version of the latter which seek to take into account the change in the technoeconomic model and the technological disparity this has caused.

As already noted, technological disparity means that while certain activities and branches will be accessible to the periphery, access to others will repeatedly be inhibited by the faster technical progress of the centres. Likewise because of the different rates of technical progress, there will be difficulties in expanding the periphery's exports away from activities where that rate is comparatively low and hence increasing their global value. Furthermore, in conditions of strong and/or growing external openness, this same technological lag will make it difficult to undertake or maintain the domestic production of tradeable goods where the peripheral countries do not possess levels of productivity and competitiveness close to those of the centres, so that they will have to resort to repeated significant increases in imports of goods whose domestic production is not viable. ${ }^{27}$

underemployment reflected in the activities of sidewalk vendors or its expansion.

${ }^{27}$ In early analyses on this subject (for example, Prebisch, 1973b, pp. 33-34 (first version: 1951)), the typical tendency of the periphery to register external imbalances was explained on the basis of the disparity between the income-elasticities of their export and import demands. A similar argument may now be put forward on the basis of "Thirlwall's Law" (see McCombie and Thirlwall, 1994),
The tendency towards a trade imbalance has a further connotation applicable to the periphery considered in abstraction or to the periphery as a whole and/or large underdeveloped economies: the impossibility of export-led growth based on the outright liberalization of those countries' markets. We will return to the importance of this further implication later.

The foregoing comments are connected with this trend, which is associated with the disparity of technical progress: this disparity adversely affects the possibility of increasing exports, while it also causes an increase in imports of goods whose domestic production is not feasible because of their technological complexity.

Underlying the foregoing argument is another more abstract argument of a structural nature. It is argued that in order to achieve sustained expansion of the production of goods and services it is necessary to comply with certain "laws of proportionality" between the activities, branches and sectors responsible for such production, or, if preferred, between the growth rates of the different components of global output. It is also argued that as production operates as a whole, these laws must also be complied with in respect of export production, production for the domestic market, and the production of the imports coming from the other pole of the system (i.e., these laws must be reflected in compatible patterns of insertion in the world economy). Thus, the explanation of the external imbalance rests on an analytical referent indicating the changes in the production structure required by its own expansion and increased complexity. ${ }^{28}$ Later on in this essay we will

which may be summed up through the expression $\gamma=\varepsilon \omega / \pi$, where $\varepsilon$ is the income-elasticity of exports; $\pi$ that of imports; $\gamma$ is the growth rate of the periphery, and $\omega$ is the growth rate of the centres. The rate of technical progress tends to be higher in the latter, and this tendency underlies the disparity of elasticities $(\pi>\varepsilon)$ and limits the growth of the periphery $(\gamma<\omega)$. As noted below, overcoming this limitation requires deliberate development policies designed to raise the periphery's domestic and external competitiveness so as to increase the elasticity of its exports $(\varepsilon)$ and reduce that of its imports $(\pi)$.

${ }^{28}$ This perception of development as a dynamic involving and requiring certain patterns of change in the production structure represents a key substrate (and at the same time a synthesis) of Prebisch's basic ideas. The presence of this perception in his work is clear from the following statements: "Economic development and the recent events are not only considered in themselves, in their episodic significance, but also as a sequence of dynamic phenomena, as living manifestations of a complex which is constantly growing and diversifying". "Economic growth is not just a question of increasing what already exists. It is a process of intense structural changes ..." (El trimestre económico, 1953, p. 46). 
return to Prebisch's views on the inability of the market to bring on these structural changes.

\section{c) Conditions for viability and efficiency}

It will be gathered from the previous section that, in order to achieve such continuity, or even to achieve high and steady growth of the product, it is necessary to impede the action of the external constraint deriving from the disparity of technical progress, by designing and implementing deliberate policies in the fields of technology and production. In essence, these policies should aim to achieve, in successive activities, the levels of productivity and competitiveness required in order to expand exports and avoid non-essential imports, so as to be able to make other imports of greater technological content that are made necessary by the disparity itself.

This deliberate guidance of external trade is considered to be a condition for the viability of development, since its aim is precisely to prevent its blockage by impeding the emergence of an external bottleneck. Such guidance is also perceived as a condition for efficiency, however, since it assumes that the process of catching up on new techniques will be carried out in a planned and orderly manner, beginning with those where it is easiest to attain the levels of productivity of the great centres and subsequently going on to those of increasing complexity, so as to reduce to a minimum the differences in productivity of the activities undertaken. ${ }^{29}$

The external constraints in the field of trade also give rise to conditionalities in the area of financial relations, the main one of these being the need to adapt the flow of external resources to the country's needs, bearing in mind that those constraints impose limits on the possibilities for remunerating those resources. In

\footnotetext{
${ }^{29}$ A formal long-term growth model which takes account of the intensity of technical progress and the income-elasticities of export and import demand may be found in Cimoli, 1988. It shows that speeding up technical progress on the periphery would enable it to diversify its efficient activities, thus transforming its production structure and avoiding an external bottleneck. It should be noted that such a transformation does not mean that the domestic and external markets should be associated with "protected" and "competitive" activities, respectively, but should instead represent two areas expressing the technological capabilities that the periphery is gradually acquiring. It may also be deduced from the model that such acquisition of capabilities favours the growth of the system as a whole and hence benefits both its poles (like the "joint industrialization" advocated by Prebisch and referred to in footnote 17 above).
}

other words, financing the development of the periphery cannot be based to a discretional or unlimited extent on foreign direct investment and external indebtedness. This means that ultimately significant levels of domestic saving are needed to ensure viable growth, although this also depends, in the final analysis, on the degree of technological disparity. ${ }^{30}$

The above recognition and brief analysis of the importance of underemployment show that it is the basis for the tendency towards income concentration and the enormous magnitude of rural and urban poverty: phenomena which express the social exclusion typical of the periphery. At the same time, however, it can also be adduced that in spite of these perverse effects underemployment nevertheless represents an available resource, and indeed a resource whose better use is a requisite for the viability and efficiency of the peripheral countries' development.

It was noted earlier that the existence of the external constraints rules out any possibility of achieving high and sustained growth rates with the export sector acting as a spearhead sector capable of inducing global economic growth. Instead, in order to keep the average growth rate at a high level it must include a substantial component of increased production for the domestic market, but this means that the domestic market must expand accordingly, so that it can absorb that proportion of rapidly increasing production targeted at it.

A stylized and extremely simplified view of this expansion of the domestic market could be expressed as an increase in employment which could gradually absorb the increases in the economically active population in modern activities and also a sustained increase in the levels of productivity of the existing underemployed workforce and the achievement of high levels of productivity among new members of the underemployed economically active population.

Such increases form the basis for the growth in domestic demand needed for strong growth: i.e., they are necessary conditions for the viability of that growth. At the same time, however, these same increases -especially the absorption of the underemployed-are a necessary condition for efficient development.

This is directly visible from a static perspective. Such absorption of itself means making better use of

\footnotetext{
30 This implication of the trade imbalance is similar to the concepts contained in Prebisch's basic ideas and the subsequent more precise formulation of them referred to in footnote 10 above. Similar arguments may also be formulated on the basis of "Thirlwall's Law" referred to earlier.
} 
the available labour and gaining fuller access to the available range of technologies. It is important, however, to approach this matter from a dynamic perspective. The fact is that over time the absorption of underemployed labour is reflected in the generation of potential economic surpluses which are of vital importance for stimulating domestic saving and capital accumulation. Furthermore, as they are a source of domestic saving, the surpluses generated by this absorption of labour help to make development viable from the standpoint of the limitations on external finance and also from the angle of the balance of payments restrictions ultimately due to the technological disparity.

Alongside the arguments put forward in the previous section, it can also be argued that there is an analysis of a structural nature underlying the foregoing considerations. The laws of proportionality governing the changes in the composition of output by branches and sectors (and even between production for the domestic and external markets) which are needed for the continuity of growth also call for corresponding changes in the occupational structure of the labour force, as well as concomitant increases in the productivity of the latter, associated in turn with the generation of surpluses that make it possible to expand production and the creation of demand conditions permitting this. ${ }^{31}$ The following section goes on to explore some aspects of such an analysis, addressing the question of the State and its role in development.

\section{The question of the State}

In his last work, Prebisch repeats and emphasizes his views on the importance of the market, but not without drawing attention to its lack of a social (equity) dimension and a proper time horizon. ${ }^{32}$

\footnotetext{
${ }^{31}$ In order to simplify the arguments still further, they were set forth earlier as a straightforward dichotomy (between employment and underemployment). Somewhat more complex forms of reasoning, however, indicate that the viability and efficiency of peripheral development do not simply depend on expanding the former and absorbing the latter. They also call for a pattern of changes in production which, by overcoming the external constraints, will bring about increases in employment and productivity in successive "technical strata" in order to increase the levels of the surplus and domestic saving in them and thus keep up high rates of accumulation and growth. It may be noted that the expression "technical strata" is taken from Prebisch's last work (1981), where it is used in the same way as in this essay.

${ }^{32}$ See Prebisch, 1981, p. 257.
}

These views may be linked with the foregoing considerations and serve to sum them up. On the one hand, the lack of a social horizon is reflected in the continuing existence of heterogeneity or, in other terms, in the employment problems which the present technological model makes still worse and which are becoming a permanent element. On the other hand, the lack of a time horizon expresses a likewise continuing tendency towards production specialization which tends to limit or impede economic expansion, through the external bottleneck.

It is considered, then, that overcoming the market shortcomings referred to by Prebisch is equivalent to overcoming heterogeneity and specialization. As we saw in the previous section, this means seeking certain patterns of change in the production structure of the periphery, leading to corresponding changes in the periphery's international linkages, as well as similarly corresponding changes in the employment structure, with successive increases in labour productivity in the different "technical strata" making up that structure.

The structuralist approach holds that the market alone is incapable of effecting this set of changes. It has been asserted in this respect that "the ECLAC theory ... (which represents it) ... may be interpreted as an early attempt to adapt orthodox economics to conditions of systemic market failure". ${ }^{33}$ Here, it is maintained that the proposals of Latin American structuralism are of a different nature: they do not refer to such imperfections, but rather to the need to fulfill certain laws of proportionality which the market is incapable of doing, even if its imperfections are corrected.

This approach, then, is "non-reductionist", ${ }^{34}$ in the sense that it does not limit the types, functions and behaviour of the agents in question to those involving supposed economic rationality, connected essentially with the guidelines given by the markets, and in this respect it recognizes that the analysis of economic phenomena (although it initially considered them in abstraction) must in the long run be carried out within a broader framework of social and political phenomena.

From this standpoint, the question of the State becomes particularly important. It directly concerns the role that the State should play in running the economy and, in more general terms, in the design and achievement of objectives which are both economic and social. This key question of the role of the State is closely linked with two others: the socio-political

\footnotetext{
33 These assertions may be found in Fitzgerald, 1998, p. 60.

${ }^{34}$ See, in this respect, Vercelli, 1991 and 1994.
} 
relations that serve as its basis, and the geopolitical relations within which it exists. ${ }^{35}$

Consideration of these matters, whose complexity has been further increased by the recent globalization process, is well beyond the scope of these notes but subject to this reservation- brief reference will be made to some points of view which seem to coincide in the present discussions on the crisis of Latin American development.

It is often noted that, in conjunction with the globalization process, a renewed and stronger presence of foreign capital and interests has been growing up in the countries of the region, and this presence is observed in more branches and sectors (especially the financial sector), with much higher levels of concentration than before. In view of its nature and magnitude, this presence has been accompanied by a reshaping of sociopolitical relations not only between internal classes and groups but also between them and foreign groups and interests. For example, there has been a change in the relative weight and connection patterns between production and/or financial interests linked with the big transnational corporations and those of an essentially local nature. Likewise, the new technological patterns -and also the bargaining power acquired by highly concentrated capital, even in its relations with the weakened public agents- affect the relations between capital and labour, reducing the capacity of the trade unions to exert pressures and the effectiveness of the latter. ${ }^{36}$

To put it another way, when a certain basic external structural relationship (mentioned in footnote 35 above) is changed, this changes the whole bases of the previous

\footnotetext{
${ }^{35}$ This dual perspective evokes the more frequent concept of dependence, which defines it as an external-internal structural relationship. According to this concept, "the action of the social groups, whose behaviour in effect links together the economic and political spheres ... (concerns both the nation and) ... its links of all types with the world political and economic system. Dependence thus finds not only its internal expression but also its true nature as a particular form of structural relations: a specific kind of relationship between classes and groups which involves a situation that structurally determines the links with the exterior" (Cardoso and Faletto, 1969, p. 29).

${ }^{36}$ It is surprising how far the flexibilization of labour markets has been promoted in different countries of the region, all at the same time. Leaving aside the different features of the efforts made in this direction, it seems clear that -albeit with differing results and to different degrees- this has been due to the weakening of trade union power. With differences of detail, various aspects of the proposals for flexibilization are dealt with in World Development Report 1995: Workers in an Integrating World (World Bank, 1995).
}

political power structure. This upset in the bases of political power, however, cannot be divorced from its surrounding geopolitical relations. The great powers usually present their own positions as the rational basis for geopolitics. On the basis of these positions, they promote changes in world trade regulations which are implemented with the intermediation and support of the main international organizations.

It is also recognized that the implementation of these changes is having profound repercussions on the countries of the periphery. On the one hand, they continue to be subject to "enormous imbalances in the conditions prevailing in international trade", yet little or no progress has been made in "building a new architecture for the global financial system". ${ }^{37}$

Those countries are therefore subjected to loose and diluted forms of control over foreign direct investment and financial capital movements. The consequent heightening of their external vulnerability is accompanied by a reduction in the leeway open to States, which are particularly restricted in various areas of short-term macroeconomic policy. ${ }^{38}$

In short, socio-political relations have been significantly changed in line with the recent globalization process, making the possibilities for their future modification and improvement more obscure and complex. In the view of the peripheral countries, the resulting changes in geopolitical relations are unfavourable for them, giving rise to a new correlation of forces which makes it harder for them to agree on an international negotiation strategy of their own. These two changes are also associated with a third change: in contrast with the recognized need for decisive State intervention, the role of the State has been reformulated in line with positions of a more or less minimalist nature, with unfavourable effects for economic management and development, as well as for the improvement of the prevailing conditions of severe social inequality. ${ }^{39}$

The previous paragraph mentions a number of negative aspects. In contrast, however, some possible alternative paths to follow may be mentioned, although they involve serious difficulties. Nowadays, any effort

\footnotetext{
${ }^{37}$ According to Faria and others (2000, p. 18).

${ }^{38}$ Ffrench-Davis (1999) gives a review of these policies in recent Latin American experience.

${ }^{39}$ Among the approaches which redefine the role of the State in line with the promotion of market-oriented development strategies, mention may be made of World Development Report 1997: The State in a Changing World (World Bank, 1997). Evans (1996) offers a review of recent approaches to the role of the State in development.
} 
to reformulate development strategies must begin with the explicit consideration of political and geopolitical equations: that is to say, with the search for broad and inclusive internal agreements and, in that connection, with the building of consensuses among countries which will reduce their weakness and help them to defend their positions in international negotiations. These agreements and consensuses form the basis for redefining guidelines on the role of the State, which, however, should also provide for proper use of its own relative autonomy. This is also important for outlining the new legal and institutional frameworks that its action requires, which in turn are related with the consolidation and deepening of democracy.

\section{Bibliography}

Burgueño, O. and L. Pittaluga (1994): El enfoque neoschumpeteriano de la tecnología, Quantum, vol. 1, No. 3, Montevideo, Universidad de la República.

Cardoso. F.H. and E. Faletto (1969): Dependencia y desarrollo en América Latina, Mexico City, Siglo XXI Editores.

Cimoli, M. (1988): Technological gaps and institutional asymmetries in a north-south model with a continuum of goods, Revista metroeconómica, vol. 39, No. 111, Bologna, Italy, Capelli Editore.

ECLAC (Economic Commission for Latin America and the Caribbean) (1953): Estudio preliminar sobre la técnica de programación del desarrollo económico, Santiago, Chile.

(1998): Cincuenta años de pensamiento en la CEPAL: textos seleccionados, Mexico City, Fondo de Cultura Económica (FCE).

El trimestre económico (1953): Documentos: exposición del Dr. Raúl Prebisch, Director Principal a cargo de la Secretaría Ejecutiva, en el V Período de Sesiones de la Comisión Económica para América Latina, vol. 20, No. 2, Mexico City, Fondo de Cultura Económica.

Evans, P. (1996): El Estado como problema y como solución, Desarrollo económico, vol. 35, No. 140, Buenos Aires, Institute of Economic and Social Development (IDES).

Faria, V. and others (2000): Preparando o Brasil para o século XXI, Brasilia, Presidencia de la República.

Ffrench-Davis, R. (1999): Macroeconomía, comercio y finanzas para reformar las reformas en América Latina, Santiago, Chile, McGraw-Hill Interamericana.

Fitzgerald, V. (1998): La CEPAL y la teoría de la industrialización, Revista de la CEPAL. CEPAL cincuenta años, special issue, LC/G.2037-P, Santiago, Chile, ECLAC.

Freeman, C. and C. Pérez (1988): Structural crisis of adjustment: business cycles and investment behaviour, in G. Dosi and others (eds.), Technical Change and Economic Theory, London, Pinter Publishers.

Hounie, A. and others (1999): ECLAC and the new growth theories, CEPAL Review, No. 68, LC/G.2039-P, Santiago, Chile, ECLAC.

Malerba, F. and L. Orsenigo (2000): Knowledge, innovative activities and industrial evolution, Industrial and Corporate Change, vol. 9, No. 2, Oxford, U.K., Oxford University Press.

McCombie, J. S. and P. Thirlwall (1994): Economic Growth and the Balance of Payments Constraint, London, St. Martin's Press.

Prebisch, R. (1946): Memoria: Primera Reunión de Técnicos sobre Problemas de Banca Central del Continente Americano, Mexico City, Banco de México (BANXICO).
(1959): Commercial policy in the underdeveloped countries, The American Economic Review, vol. 49, No. 2, Nashville, Tennessee, American Economic Association.

(1962): The economic development of Latin America and its principal problems, Economic Bulletin for Latin America, vol. VII, No. 1, Santiago, Chile, EClac.

(1963): Hacia una dinámica del desarrollo latinoamericano, Mexico City, Fondo de Cultura Económica. (1970): Transformación y desarrollo: la gran tarea de América Latina, Mexico City, Fondo de Cultura Económica. (1973a): Interpretación del proceso de desarrollo latinoamericano en 1949, Serie conmemorativa del XXV aniversario de la CEPAL, Santiago, Chile, ECLAC.

(1973b): Problemas teóricos y prácticos del crecimiento económico, Serie conmemorativa del XXV aniversario de la CEPAL, Santiago, Chile, ECLAC.

(1973c): La cooperación internacional en la política de desarrollo latinoamericana, Serie conmemorativa del XXV aniversario de la CEPAL, Santiago, Chile, ECLAC.

(1981): Capitalismo periférico. Crisis y transformación, Mexico City, Fondo de Cultura Económica.

Rodríguez, O. (1980): La teoría del subdesarrollo de la CEPAL, Mexico City, Siglo XXI Editores.

(1998): Heterogeneidad estructural y empleo, Revista de la CEPAL. CEPAL cincuenta años, special issue, LC/G.2037-P, Santiago, Chile, EClaC.

(2001): Fundamentos del estructuralismo latinoamericano, Comercio exterior, vol. 51, No. 2, Mexico City, Banco Nacional de Comercio Exterior (BANCOMEXT).

Schumpeter, J. A. (1971): Historia del análisis económico, Barcelona, Ariel.

Singer, H. (1949): Postwar Price Relation Between Underdeveloped and Industrialized Countries, New York, United Nations.

Vercelli, A. (1991): Methodological Foundations of Macroeconomics. Keynes and Lucas, Cambridge, Massachusetts, Cambridge University Press.

(1994): Por uma economia não reducionista: uma perspectiva de longo prazo, Economia e sociedade, No. 3, Campinas, Brazil, State University at Campinas.

Verspagen, B. (1993): Uneven Growth Between Interdependent Economies, Avebury, Adershot.

World Bank (1995): World Development Report 1995. Workers in an Integrating World, Washington, D.C.

(1997): World Development Report 1997. The State in a Changing World, Washington, D.C. 